\title{
FRAMING STRUCTURE IN RADICAL ISLAMIC GROUP SOCIAL MOVEMENTS: CASE STUDY OF JAMA`AH ANSHARU KHILAFAH DAULAH NUSANTARA (JADKN) AND JAMAAH ANSHARUSY SYARIAH (JAS)
}

Febriyanto

Magister of Sociology Student

Faculty of Social and Political Sciences

Universitas Indonesia

Corresponding Author: Febriyanto, E-mail:febriyanto16uisosio@gmail.com

\begin{tabular}{l} 
ARTICLE INFO \\
\hline Received: $01-07-2020$ \\
Accepted: 04-10-2020 \\
Published: October 2020 \\
Volume:3 \\
Issue:2 \\
DOI: \\
https://doi.org/10.33019/berumpun.v3i1 \\
KE \\
\hline KEYWORDS
\end{tabular}

Social Movement, Framing, JAD KN, JAS.

\section{ABSTRACT}

A social movement has various bases, one of them is religion. In the context of a social movement basic, religion can be an effective medium to mobilize people. Religion has a significant element to do the structural-developmental framing (framing process). The framing process can form a core of a moment and an event becoming a valuable experience. This experience will be organized to guide of doing an action. This research analyzes how the structure and the framing process that are done by two Islamic radical/extreme groups. While others analyze the framing structure from the media perspective, this research sees the actor of its social movement by taking the case study of Islamic radical organization namely Jama'ah Ansharu Khilafah Daulah Nusantara (JADKN) and Jamaah Ansharusy Syariahi (JAS). This research uses a qualitative method by doing an interview and document study as the technique of collecting the data. The result shows that other than similarity, these differences are found relating to the framing process and the structure executed by these two Islamic radical groups even though they are identified as the radical group as well.

\section{INTRODUCTION}

A social movement is a process done by social actors based on their interests. According to Ciurel (2018: 8), three characteristics become the traits of a social movement. First, it has conflict interests politically or culturally. In this context, there is an identifying process specifically who is its pros and cons. Second, it has connectivity or related to a group or organization informally. Third, it is oriented with the development and also the sharing of diverse collective identities. 
BERUMPUIN

International Journal of Social, Politics, and Humanities

https://berumpun.ubb.ac.id/index.php/BRP
P-ISSN: 2622-8831

E-ISSN: 2622-8335

A social movement has various bases, one of them is a religion. Soetrisno (2003) states that religion becomes an effective medium to mobilize people. One of the important elements to mobilize people is the structural-developmental framing (framing process). This perspective is in line with Goffman's statement (in Sumarwan, 2018: 250). Goffman says that framing has an important role to core a moment becoming a guide to do an action.

Research on a social movement based on a religion, especially a radical/extreme organization has been done previously. Dhenny Dwi Kunhastian (2018) conducts a study relating to the framing of news on ISIS group supporters in Tempo Magazine. This event is related to the attach that happened in Sarinah area in 2006. Nela Pristia Ariest (2016) also conduct research relating to the framing of Sarinah Bombing terror news. However, by comparing the framing analysis held by news portal Tempo.com and Kompas.com, the researches focus only on the framing process by media to the reporting about a radical/extreme group. In contrast, this research aims to examine the framing process from radical/extreme groups. in this context, it develops the people mobilization or to attract the people's interest.

Similar research has been done by A. Sumarwan (2018). Sumarwan analyzes the framing of the blasphemy which has big public attention in 2018. Sumarwan compares the framing process between Ahok's opposing groups and support groups. On the other hand, this research examines the framing process among the religion based groups that are identified as a radical/extreme group respectively. This research takes the case on the group of Jama`ah Ansharu Khilafah Daulah Nusantara (JADKN) and Jamaah Ansharusy Syariah (JAS). These two religious organizations are quite new. However, they have already had the wellknown figures and had many loyal followers.

\section{LITERATURE REVIEW}

Benford and Snow (2006: 15) explains that there are two main characters in the framing process to result in collective action. First, it is related to the oriented action function. Second, it is related to the interactive process. In the term of the interactive process, 
BERUMPUIN

International Journal of Social, Politics, and Humanities

https://berumpun.ubb.ac.id/index.php/BRP
P-ISSN: $2622-8831$

E-ISSN: 2622-8335

it has a discursive process. This process is presented in a core framing task. From this core, it has resulted in generative characteristics from the collective action frames.

Further, Benfort and Snow explain that in the emergence of a social movement, meaning and culture have a significant position (Jamil, 2018: 176). Therefore, in developing framing, meaning and culture cannot be ignored. Through the role of meaning and culture, the framing process can influence individuals and groups by the meaning of a certain situation. In addition, this case can lead to the action and solution to that situation.

From Benford and Snow's framing concept, there are three main forms of framing. Through these three forms, "consensus mobility" and "action mobility" from the actors can be paid attention.

The first form is Diagnostic Framing (Benford and Snow, 2000: 615-616). In diagnostic framing, there is a concept called injustice frames. This is deemed necessary to bring up the victims who are victims of injustice. Then, the concept of voicing the injustices that occur and defines the parties who are the perpetrators of these injustices. Here there are clear boundaries between good and evil parties. In this framing process, efforts are needed to define or look for situations and problems. In addition, some are to blame and are held responsible for the situation.

Second is Prognostic Framing. This second core form aims to find solutions and strategies to solve a problem. In this framing process, identifying specific problems and developing acceptable defense strategies.

Third is Motivational Framing. The emphasis is on building meaning through the formation of motives. The motive then becomes the basis for someone to want to be involved in a social movement.

\section{METHODOLOGY}

This research uses a qualitative approach to the type of case study. Case studies were conducted on two Islamic groups identified as radical/extreme groups. The two groups namely JAKDN and JAS. 
BERUMPUIN

International Journal of Social, Politics, and Humanities

https://berumpun.ubb.ac.id/index.php/BRP
P-ISSN: $2622-8831$

E-ISSN: 2622-8335

Researchers conducted data collection methods through interviews and document studies. Interviews were conducted with some informants from two groups. Most of them are domiciled in Solo, Central Java. Interviews were conducted by direct interviews (face to face interviews) and indirectly by telephone (telephone interview) and WhatsApp media.

So that research subjects are willing to be examined, there is an agreement on the confidentiality of the informant's identity. Therefore, the subject's identity in this study was kept secret or not mentioned. The author also interviewed several parties in institutions that handle groups that are considered extremists. The interview process for informants was conducted between October 2019 to February 2020. The document study was carried out by searching for documents relevant to the purpose of this research. The documents are studied and categorized and then analyzed.

\section{RESULTS AND DISCUSSION}

\subsection{Overview of JAKDN and JAS}

JAKDN is known by another name as Jemaah Anshoru Khilafah (JAK). In running the organization, JAKDN is guided by the pro-daulah group's sign, namely fighting for the establishment of the Islamic State in the Archipelago / Southeast Asia. In its development, JAKDN runs a strategy that has similarities with those of the Indonesian Mujahidin Council (MMI).

Regarding funding, the funds collected by JAKDN come from members' donations, alms-giving, and donations from donors and sympathizers. So far, active funding uses the Baitul Mal Al Muuqin institution, located in the city of Surakarta, Central Java. JAKDN also pioneered several Rumah Quran (RQ) and infaq institutions. The establishment of the RQallegedly-as one of the efforts to cadre and spread Daula understand, especially for children and adolescents. In addition, RQ is also used as a place of consolidation and guidance of pilgrims. The infaq institution channeled funds to movement groups (BIN, 2019). The JAKDN movement, consolidation, and regeneration efforts tend to be confidential and closed. 
BERUMMUIN

International Journal of Social, Politics, and Humanities

https://berumpun.ubb.ac.id/index.php/BRP
P-ISSN: $2622-8831$

E-ISSN: 2622-8335

This group network is quite extensive outside Solo Raya. Some members have been involved in serious terrorism cases and are part of the Jemaah Islamiya (JI) network. JAKDN has strong member militancy, high loyalty to the leadership, and centralized command. The pattern of recruitment and strengthening of network structure has also been applied in JAKDN and is still running today (BIN, 2019).

Meanwhile, JAS was declared on August 11, 2014 at the Hajj Dormitory in Bekasi, West Java. This organization group was founded by former administrators of Jamaah Ansharut Tauhid (JAT). The establishment of JAS in response to conditions of disagreement by the establishment of the caliphate by ISIS between the chief executives of JAT and Amir JAT. The leader of the JAT daily was Ustad Muhammad Akhwan, while the JAT Ustad Abu Bakar Ba'asyir (ABB). Ustad Muhammad Akhwan did not support ISIS, while ABB agreed or was more inclined to the ISIS group. The JAS group is a transfer of the name from Jamaat Anshorut Tauhid (JAT), which does not want to associate with ISIS. JAS is affiliated with the global Al Qaeda / Jabhat al Nusra group which conflicts with ISIS (BIN, 2019).

JAS study activities are routinely carried out every month and are carried out in rotation in the Solo Raya region. This was done as a step of consolidation and regeneration to JAS members to be more solid. In addition to consolidating and regenerating and conducting routine studies, JAS also made efforts to win public sympathy. JAS wants to provide learning to the community that JAS is not a radical organization, but an organization that cares about the benefit of the people (BIN, 2019). The JAS group consists mostly of figures or members of the JI organization.

Both JAKDN and JAS groups have charismatic figures who can attract and motivate their followers. The JAKDN group has one figure that is well known and has had quite a long experience in a group that is identified radically. The figure is Abu Husna. Abu Husna received support from ABB in establishing JAKDN. After its establishment, JAKDN joined the existing ISIS support group. This group also created networks for Java and Sumatra (Gunaratna, 2016: 15).

JAS is led by Ustad Muhammad Achwan. He founded JAS together with ABB's son, Ustad Abdul Rochim Baasyir (salam-online.com / 2014). Ustad Muhammad Achwan once 
BERUMPUIN

International Journal of Social, Politics, and Humanities

https://berumpun.ubb.ac.id/index.php/BRP
P-ISSN: 2622-8831

E-ISSN: $2622-8335$

joined the MMI Indonesian Mujahidin Council. He was also arrested in the Borobudur Temple bombing case on January 21,1985 . He was sentenced to life imprisonment by the New Order government, then released in the era of President Abdurrahman Wahid. Ustad Muhammad Achwan was once asked to become a temporary Amir from the JAT group after ABB's arrest (viva.co.id/am/berita/).

\subsection{Social Movement Diagnostic Framing on JAKDN and JAS}

When viewed from diagnostic framing, both JAKDN and JAS have something in common. They assume the problem of Muslims today, especially in Indonesia, is the unfair treatment that they experience. An example of such unfair treatment is the scarcity of opportunities to access economic and political resources. Both groups also identify or establish diagnostic framing as part of Muslims in other countries. Therefore, they feel the unfair treatment that befell Muslims in other parts of the world is also their problem.

In the diagnostic framing process, there is an effort to find who should be responsible for the problems that occur. JAKDN and JAS have the assumption that the mastermind that causes injustice to Muslims is a state institution or parties that are considered oppressing the Muslims. The United States is considered oppressive to Muslims, both in Afghanistan, Iraq or in other Muslim countries.

Concerning Indonesia, both JAKDN and JAS have the same understanding that the Indonesian government often does injustice. The Indonesian government is seen as an ally of the enemies of Islam, such as the American stooge, so they need to fight the government. They also assume that the legal basis used in Indonesia is not Islamic law. Therefore, they feel there is no obligation to obey the law.

\subsection{Social Movement Prognostic Framing on JAKDN Group and JAS Group}

In prognostic framing, a solution to the existing problem is formulated along with planning and strategy to support the plan. In prognostic framing, the process of identifying the cause of a problem is followed by providing alternative solutions and strategies for defense. 
BERUMMUIN

International Journal of Social, Politics, and Humanities

https://berumpun.ubb.ac.id/index.php/BRP
P-ISSN: $2622-8831$

E-ISSN: $2622-8335$

The solution or defense strategy undertaken by JAKDN is in line with the ISIS group. The JAKDN group targeted the police as the main target of their attack. This is because the police are considered as a group of harbi infidels who are enemies of Allah, Rasullullah, and Muslims (Murti, 2017). The method of attack shown by the JAKDN group is a characteristic of the action taken by the ISIS group (Nuraini, 2019).

Besides, the pattern of attacks carried out by JAKDN tends to be a single attack without any orders. In fact, it is not uncommon, involving family members in carrying out acts of terror (familial suicide terrorism). This is in line with the statement of one of the informants, namely the actions taken by members of the JAKDN group generally originate from their initiative or interpretation. According to him, JAKDN group members, after participating in a study, tended to carry out initiative activities (suicide bombings), that is without having to be ordered or asking permission from the cleric and their teacher. Thus, it can be said that the movement patterns carried out by JAKDN tend to be disorganized and are more spontaneous in nature.

In contrast to the JAKDN group, JAS groups tend not to be in line with the views shared by the ISIS group. The JAS group has the view that the ISIS group violated the creed and manhaj in the establishment of the khilafah. ISIS forces Muslims to associate with their leaders. If they disagree, ISIS does not hesitate to disbelieve fellow Muslims. As a result. in fact, it can cause divisions and animosity among Muslims (Arifin, 2015).

JAS groups are also more open to the wider community. In fact, this group develops its website and displays the activities that they have done. In addition to the content on religious lectures, social service activities are also displayed on the website. They also open access for all people who want to donate.

This was confirmed by a statement from one of the informants. The relevant informant stated, in its movement pattern, JAS is currently implementing a more open strategy, both to the community and the government. Basically, the strategy undertaken by the JAS aims to gain sympathy from the community so that they are closer to the concept of the Khilafah Islamiyah. 
BERUMMUIN

International Journal of Social, Politics, and Humanities

https://berumpun.ubb.ac.id/index.php/BRP
P-ISSN: $2622-8831$

E-ISSN: $2622-8335$

Prognostic framing from JAS has a significant difference from JAKDN. JAKDN places more emphasis on struggle and influence with violence, even to suicide bombings. The JAS places more emphasis on social services of community services, such as blood donor activities or social service activities. Based on the framework of the framing structure in social movements, what is done by the JAS and JAKDN groups is one form of strategy. In this case their strategy in attracting the attention and sympathy of the community, but with a different framing.

\subsection{Social Movement Motivational Framing on JAKDN Group and JAS Group}

In motivational framing, there must be a strong reason. Through it other people want to be involved together in social movements. Forming these motives can be done by developing and creating words that can motivate others.

JAKDN and JAS have motivational framing which is not much different. Their motivation to move members is because of the existence of the teachings of the Islamic religion instructing them to uphold the teachings of religions that are following sharia. Both groups also equally motivate their members and the community to carry out jihad and want to create a state based on sharia law.

What makes the difference in motivational framing between the two groups is that JAKDN tends to motivate its members to commit amaliah or jihad through violence to anyone outside their group. For example, by committing suicide bombings. By saying there is a guarantee for those who do that, that is, they will get heaven's reward on the last day.

JAS on the contrary prioritizes the consideration of the benefits and losses of decisions to be taken to avoid amaliah that could cause damage. JAS motivates its members to uphold the teachings of Islam without having to take actions that can cause divisions within Muslims.

\section{CONCLUSION}


BERUMPUIN

International Journal of Social, Politics, and Humanities

https://berumpun.ubb.ac.id/index.php/BRP
P-ISSN: $2622-8831$

E-ISSN: 2622-8335

In social movements, one important element to consider is the framing process or framing structure. Through that, actors can build/mobilize/influence the sympathy of supporters or the people.

In social movements carried out by Islamic groups identified as radical groups, there is a framing process that is not always the same. This is found in the case of two groups, namely JAKDN and JAS. Each of them builds framing to build the foundation and direction of the organization. Framing is important to build and also influence the movements made by followers. The framing process of the JAKDN and JAS groups is not merely a narrative construction on law enforcement and the teachings of Islam, but also has a close relationship with their respective interest factors to attract public support.

The framing equation between JAKDN and JAS lies in diagnostic framing. This equation is a problem that occurs in Muslims today are Muslims in an oppressed condition due to injustice and not upholding the teachings of religion and Islamic law.

There is a difference in prognostic framing. The movements carried out by the JAKDN group resemble those of ISIS. JAKDN provides solutions to problems through violence. The JAS group directs their activities to the activities of social services.

In motivational framing, both JAS and JAKDN groups have similarities, but also differences. The similarity is that what they do is like a religious order and can get rewarded rewards. The difference is that JAKDN generally commits jihad through violence, such as suicide bombing and others. Meanwhile, JAS emphasizes social service activities and the unity of fellow Muslims. In essence, these two things are done to attract attention and move the members of the group and the wider community.

\section{REFERENCES}

[1] Benford, R.D. \& Snow, D.A. (2000). Framming Processes and Social Movement: An Overview and Assesment. Annual Review of Sociology, 26 (1), 611-639.

[2] BIN. (2019). Pemetaan Jaringan Organisasi Islam Radikal di Indonesia. Jakarta: Badan Intelijen Negara. 
[3] Creswell, J.W. (2014). Research Design: Qualitative, Quantitative, and Mixed Methods Approaches. SAGE Publications, Inc.

[4] Eddyono, S.W. \& Anggara. (2016). Mendefinisikan Terorisme: Pemetaan dan Rekomendasi Pelapor Khusus PBB terhadap Definisi Terorisme yang lebih Komprehensif dan Universal. Institute for Criminal Justice Reform (ICJR).

[5] Hamdi, Imam. (2016). BNPT sebuat ada 2,7 juta orang Indonesia terlibat terorisme : 20 Januari 2016. https://nasional.tempo.co/read/737905/bnpt-sebutada-27-juta-orangindonesia-terlibat-terorisme.

[6] Junaid, Hamzah. (2013). Pergerakan Kelompok Terorisme dalam Perspektif Barat dan Islam. Jurnal Sulesana, Vol. 8 No. 2 Tahun 2013.

[7] Kunhastian, D.D. (2017). Konstruksi Berita Dalam Majalah Tempo (Analisis Framming Pemberitaan Terorisme di Majalah Tempo Edisi Januari - Februari 2016). Skripsi. Universitas Muhammadiyah Surakarta.

[8] Mubarak, Zulfi. (2012). Fenomena Terorisme di Indonesia: Kajian Aspek Teologi, Ideologi, dan Gerakan. Jurnal Salam Vol. 15 No. 2 Desember 2012.

[9] Moleong, Lexy J. (2010). Metodologi Penelitian Kualitatif : Edisi Revisi. Bandung: PT. Remaja Rosdakarya.

[10] Neuman, W. Lawrence. (2007). Basics Of Social Research (2 ${ }^{\text {nd }}$ ed.). USA: Pearson Education, Inc.

[11] Sahrasad, Herdi \& Chaidar, Al. (2017). Fundamentalisme, Terorisme, dan Radikalisme Perspektif Atas Agama, Masyarakat, dan Negara. Freedom Foundation \& Centre for Strategic Studies - University of Indonesia (CSS UI).

[12] Sefriyono dan Mukhibat. (2017). Radikalisme Islam: Pergulatan Ideologi ke Aksi. Jurnal Al-Tahrir, Vol. 17 No. 1 Mei 2017.

[13] Setiaji, Koni. (2014). Terorisme dalam Bingkai Media (Analisis Framming Pemberitaan Terorisme di Surakarta pada Headline Koran Solopos Edisi Agustus September 2013). Skripsi. Universitas Muhammadiyah Surakarta. 
BERUIMPUIN

International Journal of Social, Politics, and Humanities

https://berumpun.ubb.ac.id/index.php/BRP
P-ISSN: 2622-8831

E-ISSN: 2622-8335

[14] Sumarwan A. (2018). Memahami Framming Gerakan Sosial. Jurnal Basis, No. 1-2, Tahun ke 67, 2018.

[15] Wiktorowicz, Quintan. (2005). A Genealogy of Radical Islam, Studies in Conflict and Terrorism. 28: 75-97.

[16] Wiktorowicz, Quintan (Ed). (2012). Aktivisme Islam: Pendekatan Teori Gerakan Islam. Terjemahan oleh Tim Penerjemah Paramadina. Jakarta: Democracy Project Yayasan Abdi Demokrasi. 